\title{
Anderson and the legacy of Free Cinema
}

John Izod and Karl Magee

Stirling Media Research Institute 20 May 2014

In March 1986 ITV transmitted Lindsay Anderson's contribution to the Thames Television series British Cinema: A Personal View. It was an illustrated lecture based in his personal history, Free Cinema 1956 - ? An essay on film. Still smarting from the sense of defeat caused by the way Britannia Hospital (1982) had been derided by British reviewers and ignored by his countrymen, ${ }^{\mathrm{i}}$ Anderson closed his programme by asking whether Britannia Hospital was the last Free Cinema film and answered his own question, "Time will tell., ,ii

Several reviewers remarked, like Penelope Houston, that Anderson had failed to recognise his fellow British directors who had continued the Free Cinema tradition. She cited Stephen Frears, Peter Smith, Bill Douglas and Bill Forsyth, adding that Anderson had described Free Cinema so that it looked 'like a more exclusive club than it had ever seemed in its heyday. ${ }^{\text {,iii }}$ Brian Baxter added Ken Loach and Terence Davies to the excluded, ${ }^{\text {iv }}$ while Richard Last and Walter Burns resisted Anderson's contention that Free Cinema had died in the materialistic 1970s. He had ignored a body of filmmaking in similar vein to Free Cinema which had moved from the large screen to television. ${ }^{\mathrm{V}}$ Accepting, then, that the legacy of Free Cinema can be seen on British screens, we shall investigate whether the same can be said of Anderson's own work after the mid 1970s - both the films he released and those left uncompleted.

For five years to the end of 1980, Anderson sought opportunities to make films within the Hollywood system. Several studios were interested in him thanks to his track record with If ... (1968) and O Lucky Man! (1973). One of them, Columbia Pictures, invited him in 1976 to direct a film version of James Fenimore Cooper's classic story The Last of the Mohicans. ${ }^{\mathrm{vi}}$ As it happened, Anderson had begun that spring with his friend and former Sequence colleague Gavin Lambert to develop an idea for a film loosely based on an Arnold Bennett novel. Anderson seized the opportunity and pitched the idea of The Grand Babylon Hotel to enthusiastic executives at Columbia. 
They signed a development deal ${ }^{\mathrm{vii}}$ and Lambert began to write a script with input from Anderson. Bennett's novel had used the hotel as starting point for a whirlwind adventure around Europe, but Anderson and Lambert decided to confine the action to the hotel, a living presence in the story. ${ }^{\text {vii }}$ They moved Bennett's tale of espionage and intrigue from 1900 to 1912 to focus the plot on events leading to the outbreak of the First World War, ${ }^{\mathrm{ix}}$ a period better suited to the epic drama they had in mind. ${ }^{\mathrm{x}}$ However, a major change of personnel at the top of Columbia Pictures in early 1977 led to the project being dumped, victim of intra-studio politics - or so Anderson told Lambert, possibly to save his feelings. ${ }^{\text {xi }}$ Writing to Daniel Melnick, Columbia's new CEO, Anderson accepted both that Lambert had not risen to the complexity of plotting on the epic scale required and the story provided too few interesting leading roles to justify such an expensive production. Nevertheless Anderson looked forward to finding a subject that he could do for Columbia, 'to our mutual enjoyment and satisfaction. $^{\text {xii }}$

Columbia's new management did indeed want to retain Anderson and immediately sent him a script to consider. He judged it 'the biggest mish-mash of pseudosophisticated rubbish I have ever read. ${ }^{\text {xiii }}$ This was John Carpenter's script which, directed by Irvin Kershner and starring Faye Dunaway, was released in 1978 as The Eyes of Laura Mars. Anderson's long-established reluctance to make a mainstream Hollywood movie had resurfaced. He complained to Columbia's British Productions department,

It is really maddening - and galling as well - to feel that interest on the Coast for anything British is very superficial and unlikely to be supported. I find it awfully hard to take seriously the idea of doing an American picture, when the approaches from Hollywood are so thoughtless and amateurish. On the other hand, is there really any possibility that Columbia would ever be interested in a successor to the kind of films which they claim to admire so much - i.e. This Sporting Life and/or If....? ${ }^{\mathrm{xiv}}$

The studios were probably less interested in those films than their director - someone with a track record superficially resembling John Schlesinger's - whom they perhaps saw as another Briton who could move from directing art house films to mainstream fare. 
In courting Anderson, American companies had competition from EMI which offered him a number of projects. Its chief executive Lord Delfont wanted him to direct a historical drama based on the life of Edward II. While film adaptations of Christopher Marlowe's play had been made previously, this one would be based on a new script. Anderson was approached in January 1978 but, believing the designated producer unsuited to this project, and doubtful the latter could find a scriptwriter to provide the changes he required, quit in April. ${ }^{\mathrm{xv}}$

Anderson's determination to continue the Free Cinema tradition seems to underpin preparations for two other films that were not seen through to production. He had for some time considered adapting Evelyn Waugh's novel Vile Bodies (1930), first discussing the possibility with Warner Bros. in 1976. The novel, set in the period following the First World War, follows the decadent lives of a group of young socialites as they party their way around London. For Anderson, 'the unique quality of Vile Bodies is its evocation, both satirically and in a certain way poetically, of an entire era. Of course there are individual relationships and characters, but they are important chiefly as part of a vast, witty, hilarious and finally quite scathingly satirical fresco. ${ }^{\text {xvi }}$ What 'epic fresco, ${ }^{\text {xvii }}$ could better have suited a director who might happily have applied the same words to O Lucky Man!? The idea fell through because Warner Bros. had in mind a tight budget that would not cover the extravagant epic that Anderson had in mind. ${ }^{\text {xviii }}$ Four years previously the studio's head of distribution had characterised box-office returns from Anderson's O Lucky Man! (which Warners financed) as 'not good' xix Conceivably the studio was reluctant to invest heavily in another satire by the same director.

Following the success of the 1979 TV adaptation of Brideshead Revisited, interest in adapting Waugh's works revived. In September 1980 Anderson signed a deal with EMI to write a screenplay of Vile Bodies with Charles Wood ${ }^{\mathrm{xx}}$ and enjoy first option on directing. Considerable time and effort was spent developing the project; but the departure of the original producer (Bob Solo) led to EMI's interest waning. This, coupled with Anderson's unhappiness with early drafts of the screenplay, ${ }^{\mathrm{xxi}}$ caused him to withdraw in November $1980 .^{\text {xxii }}$ 
Meanwhile, in December 1979 Anderson and Michael Medwin (his producer on If.... and $O$ Lucky Man!) had signed a development deal with $20^{\text {th }}$ Century Fox for a film based on a script entitled 'Report from the Sex Factory'. The draft, written by Ian Rakoff (Anderson's assistant editor on If ....), followed the adventures of an English film editor working on a high-budget European porn movie who falls in love with one of the film's stars. Rakoff himself had in 1975 taken a job in Holland editing a film called Sensations for Alberto Farro, the director he described as 'the Fellini of porn'. xxiii On reading Rakoff's diary chronicling his experiences, Anderson saw its cinematic potential for developing 'certain highly dramatic, highly absurd contemporary themes, ${ }^{\text {xiv }}$ and the two men developed the project.

Although the subject was potentially controversial, Fox thought that an established director like Anderson (who had handled adult scenes in O Lucky Man!) would prevent the film from being, as they put it, 'too blue. ${ }^{\mathrm{xxv}}$ However, as discussions progressed it became clear that Anderson didn't share Fox's ideas. Writing to Anderson in September 1980 a Fox executive summed up the difficulties that led them to turn down the film.

... your point of view and attitudes towards the material are on a totally different line from those of Fox and as we were really talking about two very different approaches, I do not think that we would ever come up with material that would totally satisfy both parties. ${ }^{\text {xxvi }}$

No evidence survives in Anderson's files to reveal what these differences of opinion might have been, but before Fox pulled out, Anderson wrote to his friend the Variety critic Gene Moskowitz, 'Unfortunately I'm beginning to feel more and more that no major studio is likely to be attracted to a script that bears my personal stamp. Too offbeat and eccentric. ${ }^{\text {xxvii }}$ The present authors are tempted to speculate that Anderson wanted to present a 'highly absurd,' satirical exposé of pornography's seedy underbelly - a scabrous piece of Free Cinema. However, Rakoff's draft script is not sufficiently developed to enable us to judge how it might have turned out. ${ }^{\text {xxvii }}$

Satire was certainly on Anderson's mind in 1977-8 after he accepted Stephen Frears's invitation to direct one of six plays written by Alan Bennett for London Weekend Television. Anderson made it a condition that he should have creative input to 
scripting The Old Crowd and the two men worked together well. Anderson led Bennett in making the house party of nouveaux riches buffoons less amusing and more Bunuelesque, satirical and disturbing than in Bennett's earlier draft. ${ }^{\text {xix }}$ Largely because it formed part of a Bennett season, was made for television and has only been available in extracts since its transmission, The Old Crowd, a substantial item in Anderson's screen work, tends to be undervalued. ${ }^{\text {xxx }}$

The male characters are wealthy toffs and rabid commentators on social issues; the females gossip vacuously and plot sexual adventures. Their prejudices blind them to the root causes of the malaises on which they pontificate. As Erik Hedling observes, the venue for the party is itself blinded by old newspapers pasted over the windows, 'the modern press accordingly being reduced to a screen which blocks out real views of the outside world. ${ }^{\text {xxxi }}$ A hint of incipient blindness dulls the décor too: the action takes place in a turbid interior, the men wear tuxedos while the women's dresses provide almost the only colour. It makes them stand out both as symbolic bearers of their husbands' wealth and objects of other men's lust (their spouses being indifferent to their sexuality). Meanwhile, the actors project their voices grandiosely as if on stage. Rather than in naturalistic mode clipping each other's lines, they leave pauses before responding. And when the camera pans, it occasionally reveals other cameras and technicians. A few shots are recorded in monochrome, another feature of the Brechtian distancing machinery that Anderson preferred in his satires.

As Peter Hoskin noted, the world outside mirrors the crumbling inner world of the boorish and self-centred characters. It appears beset by riots, rampant crime, disease and (in the eyes of the privileged bourgeoisie) the collapse of public services. 'This bleak portrait would resonate for viewers enduring the ongoing "winter of discontent" that prefigured the demise of the Callaghan government. ${ }^{\text {xxxii }}$

Concerning the original Free Cinema objectives, Anderson wrote in 1957, 'Our aim is first to look at Britain, with honesty and with affection. To relish its eccentricities; attack its abuses; love its people. To use the cinema to express our allegiances, our rejections and our aspirations. This is our commitment. ${ }^{\text {xxxiii }}$ The group's manifesto declared their intention to link polemic and aesthetics: 'An attitude means a style. A 
style means an attitude. ${ }^{\mathrm{xxiv}}$ The Old Crowd served these values as the production and Anderson's essay on it affirm.

A dissident or subversive vision demands a style that rejects the terms in which the conforming world presents itself: this is the only way it can offer a version of reality in essentially different, critical terms. The dissenting artist must hack away the props which hold up the status quo, in style as well as theme. ${ }^{\mathrm{xxx}}$

As Anderson well knew, there is a risk that, when one tries to alienate audiences' sympathy, those efforts may succeed in arousing resentment, even anger. If the overwhelmingly hostile press reviewers reflected the opinions of their readers, Anderson had succeeded (Bennett was excused). A decade later, he still found it gratifying that the play had been disliked and caused a stir. ${ }^{\text {xxxvi }}$

In January 1979 Anderson signed a development deal with Orion Pictures in Hollywood to develop a number of film projects. Initially the scripts sent for assessment did not impress him, but eventually two caught his attention. They were very different from each other - a reminder that his interests were never confined to Free Cinema. One was a remake of Nicholas Ray's In a Lonely Place, a 1950 thriller starring Humphrey Bogart. Despite protracted discussions, Anderson and Orion could not agree on a scriptwriter. ${ }^{\text {xxxvii }}$ The other was Empire, an historical epic set in India at the time of the Great Mutiny of 1857. This, the second historical drama he had been offered in a year (after Edward II), drew him back to the land of his birth. He went to scout locations where Indian troops had mutinied against British command, sparking a rebellion which spread throughout northern India. Orion envisaged it as 'an exciting, popular story', ${ }^{\text {xxviii }}$ and wanted the romantic interest between a British Lieutenant and an Anglo-Indian woman emphasised to 'give the script a strong emotional base'. ${ }^{x x i x}$ Once again Anderson lost interest through doubts about the script and his commitment to other projects, not to mention Orion's dwindling enthusiasm. ${ }^{\mathrm{xl}}$

At the end of 1980 Anderson needed to choose between four projects. Warner Bros. had invited him to direct Dress Gray, a film scripted by Gore Vidal and based on Lucian Truscott's novel about the murder of a cadet at an elite American military college. Anderson, Vidal and producer Richard Roth met on a number of occasions in late 1980 and early 1981 to discuss script rewrites, and actors were auditioned. ${ }^{x l i}$ 
Secondly, Orion Pictures wanted Anderson to work on Wolfen, a crime/ horror film. Thirdly, he had an invitation from the National Theatre in England to direct Hamlet on stage in Stratford. Fourthly, his and David Sherwin's script of Britannia Hospital had been going round the studios for some time without securing production funding. Having in the summer of 1980 engaged Clive Parsons as producer and charged him with raising finance for Britannia Hospital, Anderson now consulted him on how to proceed. Parsons recommended that he should do Dress Gray and Britannia Hospital since both were ready to go into production. He expressed confidence that Warners would wait for him until January 1982 if funds for his own film did come through. ${ }^{\text {xlii }}$ Within forty-eight hours, however, Anderson made a different decision, one which he rightly anticipated would be crucial to his own professional future. He crystallised the tensions underlying his thinking in a diary entry.

Last night I made the decision - to agree to 'Hamlet' at Stratford (Theatre Royal) [...] to stick with Britannia Hospital or rather to gamble on Clive Parson's ability to set it up - tho' inevitably postponing its shooting (if he does set it up) till, say, August ... and so (seemingly inevitably) saying goodbye to yet another Hollywood flirtation - Dress Gray.

Wisdom or folly? Courage or cowardice? I haven't the slightest idea. I've always known that I haven't the talent to plan or order a career - a life for that matter. I can see all round every question far too clearly. From one angle Dress Gray would be a revitalising, challenging, freshly creative experience. From another it would be an evasion, a running-away, a rash committal of myself into the hands of ruthless aliens - however seemingly friendly ... From one angle Britannia Hospital is the logical, courageous development of my own style, my own thoughts and feelings. From another it is a stubborn repetition of ideas which have already proved unpopular, unwelcome, unacceptable to all except an increasingly shrinking minority. ${ }^{\text {xliii }}$

While Britannia Hospital was in post-production, Anderson told a journalist that his ambition was to make it an example of Free Cinema. ${ }^{\text {xliv }}$ He described it to Satyajit Ray as,

a natural, or at least a compulsive development out of the ideas and style evolved out of The White Bus ... through If ... and O Lucky Man! ... That's to say in the genre of satirical epic, hopefully with humour, but without very much 
softness, sentiment or indulgence towards the follies of human kind. Lyricism generally of a rather harsh, absurdist kind. 'Epic' in structure, which means that there's no really leading character, only a group of characters and an over-all theme - a form that's extremely hard to manage artistically, and very difficult to make popular. ${ }^{\text {xlv }}$

This gives a fair account of the film's register, as does something Anderson had said to David Robinson in 1973: 'What I like about [O Lucky Man!] is that it has that irony. It hasn't got the simplicity of being nasty about rich people. It's nasty about poor people as well. It's nasty about people. ${ }^{\text {xlvi }}$ This is even truer of Britannia Hospital, which, with its hard-core Swiftian satire, culminates the trend toward black humour in his 'epics'. In large part, an expression of his despairing scrutiny of late 1970s Britain, it features a huge cast. Yet no single character invites audience sympathy unless, like Mick Travis's lover, to betray it. And this third Travis (Malcolm McDowell again) is not the picaresque hero expected by spectators who knew his predecessors, but a selfsatisfied investigative television journalist verging on middle age. As Hedling says, he is a side character, swallowed up by the narrative, an absence that leaves the audience with no focus for their emotions. ${ }^{\text {xlvii }}$

We have mentioned that Anderson included in the necessary characteristics of Free Cinema the director having freedom of personal expression, a poetic style wed to social commitment, and independence. In the case of Britannia Hospital, Anderson realised the script he had co-authored with Sherwin, and the upshot was a film indelibly marked with his authorship. ${ }^{\text {xlviii }}$ Although it is not the kind of factual film envisaged by the Free Cinema group (being far closer to lampooning 1970s Britain than presenting social-realist documentary), its satirical bent and abrasive style vouch for his radical personal commitment. In making the film Anderson had enjoyed the creative freedom that a Free Cineaste would want. However, like most filmmakers whose distributors are principal funders of their features, he lacked executive authority to release the production how, when and where he chose. EMI wanted to recover its capital outlay in timely fashion; but hindsight reveals that the company (like Anderson who did not dissent) misjudged the market in launching the film 
against a riptide of British jingoism stirred by war over the Falklands. It ensured most British reviewers' antipathy and probably hit the box office too. ${ }^{\text {xlix }}$

In the mid 1980s Anderson and Sherwin thought about making a sequel to If ...., inevitably another heir to Free Cinema. Throughout the various outlines and drafts, one idea remains constant - that the main characters of the original should return to the school for a reunion twenty five years later: Mick Travis (once again McDowell) has become a Hollywood movie star; Wallace is a navy officer who has lost his arm on active service; while Johnny serves as a priest working in a run-down area of Liverpool. Their nemesis Rowntree (who in the original film thrashed them in the school gym) is now a Minister in a Conservative government, tipped to be the next Prime Minister - and his daughter is head-girl at the school, which is now co-ed. The temptation to have these characters revert to ancient grudge matches offered Sherwin and Anderson irresistible opportunities for satire.

They worked intermittently on If (2).... until Anderson's death in 1994, but with no diary entries between 1987 and 1991 and few in 1991 or 1992 (when they end) it is hard to establish how serious Anderson was about making this film. He secured development money from the UK National Film Development Fund in 1986, ${ }^{\text {li }}$ and in 1993 from Paramount Pictures. But as he noted in letters to friends, his writing partner David Sherwin badly needed financial support. Anderson appears more concerned with helping his friend than enthusiastic for the project. ${ }^{\text {lii }}$

When the management of the pop group Wham! dismissed Anderson as director of the film he called If You Were There... (Wham! in China) (1985), he was able to retain a copy of his rough cut. The film he had been making followed George Michael and Andrew Ridgeley on a short concert tour in China. By 1985, Anderson's competence to fulfil such a remit was beyond question. He had made numerous television commercials and an effective public information film Foot and Mouth (1955). In January 1984 he had directed a cheerful pop video for the singer Carmel, 'More, more, more'. liii Undoubtedly he could have directed a publicity film for Wham! in the same genre - the kind of piece eventually realised in Foreign Skies which was cut from his footage after the group fired him. liv 
Anderson's papers reveal that Wham! managers appointed him without a clear remit. They had left planning to an inexperienced producer before hiring him to direct and Anderson found them unsure of what they wanted. Even in the early stages of editing 'miles and miles of material - some of it excellent, much of it unusable', ${ }^{\text {lv }}$ Anderson was complaining, 'I don't honestly know whether we are making a film or a video or a TV programme... Perhaps all three. ${ }^{\text {,lvi }}$ That may explain why his work, which by no means fostered adulation of the two stars, was rejected. There is abundant evidence in the rough cut to show that, had it been completed on Anderson's terms, it would have been poetic, personal to him and have expressed an attitude. It would also have been socially aware, presenting a commentary on the gap between past and present represented respectively by ancient Chinese culture and the appetite of young people to engage with the West. ${ }^{\text {lvii }}$ In short, it would have sat well in Anderson's Free Cinema tradition had it not been subject to the pressures of commercial pop music.

Devices characteristic of Free Cinema appear at their richest in the climactic section of the rough-cut, Canton Concert. It starts with the band on stage performing a highenergy number but then cuts to the city streets at rush hour. People wash in the great Pearl River. Ferries move through the water and for some moments the sound track is occupied by river sounds. Barges pass across the screen, viewed through telephoto lenses, while the sailors (and on one boat small children playing) look back at us as if from another universe - a touching homage to Jean Vigo's L'Atalante. Then, as the orange sun silhouettes people going home over a metal bridge, Anderson and his editors overdub the long, elegiac saxophone introduction to 'Careless Whisper'. With the sound of applause rippling as if in the distance, the lissom music courses over these relaxed images blending all in a momentary exquisite unity. When we cut back into the concert hall, George Michael, singled out by a spotlight, pulls the energy which that prelude has built into a beautifully expressive solo. It is a superlative example of Anderson, his director of cinematography David Myers, and his editor Peter West applying a technique the director learnt thirty-five years earlier from Humphrey Jennings to create an edit in which art aspires to the condition of music.

The Whales of August (1987) was based on David Berry's stage play about two elderly sisters sharing a summerhouse on the Maine coast. Its screen rights had been 
acquired by a publicist Mike Kaplan for whom the project was a personal obsession; and a small American distributor financed the project. Once hired, Anderson quickly took on a script rewrite, altering Berry's text to meet the needs of the big screen. Kaplan, though involved in the entire process, was a producer who did not force ideas on his director even when, in the late stages of post-production, he sent seventeen pages of notes to the editor, Nicholas Gaster which the latter rejected as impracticable. ${ }^{\text {lviii }}$ Somewhat to Anderson's pleasure, Embassy Home Entertainment had agreed to distribute but had not bought the right to interfere in the creative process. ${ }^{\text {lix }}$ He told Louis Marcorelles that Embassy had rejected the project as insufficiently commercial, and added that on location in Maine they were away from studio pressure and close to the spirit of Free Cinema. ${ }^{\text {lx }}$ He reaffirmed in another interview that he thought of the film as one of the last vestiges of Free Cinema, happy that its style was opposed to the currently fashionable technical feats, which he disliked. $^{1 \times i}$

The resultant film is a chamber piece, in several respects analogous to David Storey's play In Celebration which Anderson had brought to the screen in 1974 for Ely Landau's American Film Theatre. No accident then that, before flying to New York to start redrafting the screenplay, Anderson called on Storey for advice on the structure of The Whales. ${ }^{\text {1xii }}$

It is fair to describe both these films as being close to the Free Cinema tradition without unambiguously forming part of it. Each had first been a stage play; each was a small-scale production made without creative interference from financiers; ${ }^{\text {xiii }}$ and each dwelt on intimate and painful family emotions both directly and indirectly engaging with contemporary society. These resemblances make it productive to consider them in tandem.

In the case of In Celebration, the tensions between the characters threaten to wreck a family reunion and have an unmistakeable social dimension. The father, a coal miner, has given everything to ensure that his sons do not have to go down the pit. However, their educational attainments have pushed all three young men into worlds remote from their parents, severing them from their roots. 
Anderson had directed the first stage production of In Celebration at London's Royal Court Theatre in 1969. In 1973 Otto Plaschkes (producer) invited him to direct a film version for Ely Landau's American Film Theatre. For the film, Anderson succeeded in reuniting the original cast (Alan Bates, James Bolam, Constance Chapman, Brian Cox, Gabrielle Day, Bill Owen) finding that the actors' performances had matured. This was partly because, five years on, they were closer to the characters' ages, whereas some had been a little young for their roles at the Royal Court. ${ }^{\text {lxiv }}$ Their familiarity with the production also contributed to a sense between them of a real family. ${ }^{\mathrm{lxv}}$ Anderson told a journalist, 'It became more mature. I felt it was a deeply personal commitment on my part and that of the actors. ${ }^{\text {, } x v i}$

Another factor, Dick Bush's skill as director of photography in working in tight setups, adds to the sense that through its intimacy the film honours the legacy of Free Cinema. From the results of their work, Anderson recognised that he might have been at risk of underestimating,

the power of the camera to create and register psychological movement, by the use of expressive grouping, and of course most strikingly through the use of close-up. This meant that a character like Steven [...] who is very hard to bring off on the stage, since he is silent for so much of the time, and one can't be sure that the audience is going to be looking at him, or continuously aware of him, as is necessary - a character like this can be correctly "placed" much more easily in a film than on the stage. I suppose that what the film does most successfully, from my point of view, is to oblige the audience to look at it as exactly as I directed it. They can't let their attention be distracted by the irrelevant face or movement, as it might be on the stage. At each moment they have to see and attend to exactly what I, as director, wished them to. Since I am nothing if not authoritarian as an artist, this is quite a joy for me. ${ }^{\text {lxvii }}$

Benedict Nightingale, reviewing the film on Radio 3, Critics Forum caught the transformation effected by the visual style in transferring In Celebration from the stage. 'At the Royal Court I remember it being much more a social document about the sons' loss of roots, loss of cultural identity. Here it becomes far more - with the close-ups on these very expressive faces - far more about the lies, the pretences, 
within the family, the well-meaning wrongs done by parents to children. A family drama., ${ }^{\text {,xviii }}$

In The Whales of August two elderly widowed sisters, played by Bette Davis (Libby) and Lillian Gish (Sarah) return to the house where they have taken annual summer holidays since childhood. Libby is crotchety, blind and almost totally dependent upon Sarah who, though strong in will, finds it hard to cope with her sister's querulous insults. The Whales focuses on the relationship between these two characters but goes beyond it when neighbours, one of them sublimely unconscious of the sisters' rights and needs, try to encroach on their home for their own advantage.

The lyricism of both In Celebration and The Whales of August brings to mind John Ford, whom Anderson admired intensely. The two films have styles (as Ford's often did) typified both by subtle framing that reveals the characters' personalities and links them to their environs, and also a measured editing pace that gives the actors time to make their performance visually effective. Both films have been described as Chekhovian. The association is fitting: Anderson directed The Cherry Orchard on stage in 1966 and 1983. In the last three years of his life he tried with Yaffle Films to develop the play for cinema. ${ }^{\text {lxix }}$ The epithet captures the sense the two films generate (like Chekhov's play) of apparently unaltered family life in which, all unseen, time enforces painful changes and offers only limited compensations for its passing before the farewells (no less poignant than in Ford's work) mark the end of an era. ${ }^{\text {lxx }}$ Among the small rewards for suffering perhaps the most profound is the characters' reluctant discovery of a measure of acceptance.

Glory! Glory! (1988), a two-part drama made for HBO cable TV, certainly cannot be described as a personal work for the director. Not only was scripting at an advanced stage when Anderson was invited to direct, but each of the four corporations involved in financing appointed producers (eight in all) to secure the rights of their respective companies. ${ }^{\text {lxxi }}$ Anderson soon discovered that power was concentrated not on the director but 'the deal-making producers', executives who in his opinion lacked the cinematic nous of those for whom John Ford had worked in the mid-twentieth century. ${ }^{1 x x i i}$ He noted his sense of detachment from a production system that was alien to him but resolved that the big fee should soothe his aversion, admonishing himself 
to 'Think of the money' lxxiii Although the project had a social dimension and originally attracted him for its satire on flagrantly exploitative American televangelism, he had to give way, after a struggle, to the producers' insistence that satire for American subscribers to cable TV stations such as HBO had to dispense with saeva indignatio in favour of being entertaining rather than scabrous. ${ }^{\text {lxiv }}$ For these reasons Glory! Glory! cannot be reckoned as Free Cinema.

That said, in his own record of events it sometimes seems as if, had Anderson had got his way, the show might have turned out as a more personal venture - this despite work schedules that weighed on him. The producers had under-budgeted and, after running into unforeseen financial constraints, refused to extend the three weeks allowed for editing. Anderson and his editor Ruth Foster decided to complete the job without pay over a further three weeks. ${ }^{\text {lxxv }}$ This was when the personal magic of filmmaking struck home once again for Anderson. Not for the first time, he found it impossible to remain detached when cutting film 'even a film for TV'. lxxvi

The real attachment, as far as I'm concerned, comes in the time of editing, the time of intimate and scrupulous work on the material, when one's whole effort and concentration and feeling goes into the rhythmic ordering, the exact pointing by cutting and juxtaposition of every foot of film we have shot. It is at this stage that film most closely corresponds to Pater's dictum that "all art constantly aspires to the condition of music". And I am reminded of Coleridge's phrase, "shaping spirit of imagination"... In editing, obsessiveness is all. Absolute accuracy of timing, (which is the basis of all important rhythm) is essential: every imperfection must be ironed out, or disguised, or worked around, to create the whole that will be (seen to be) as seamless, as expressive, as rhythmically satisfying as possible... we are compelled to struggle for perfection, compelled to run on in pursuit of Milton's "immortal garland", compelled to stretch out, ever seeking to grasp the inviolable shade. That is one of the definitions of the word "Artist". lxxvii

Plainly during those days of editing Glory! Glory! Anderson felt the excitement of making something that had belatedly become of personal significance. To that extent he was returning to the ethos of Free Cinema, and this comfortable feeling was nurtured by the producers' warm reception for the first private screening. ${ }^{\text {lxxviii }}$ For 
some weeks he forgot that they had the final cut until without forewarning him, Bonny Dore exercised that right and left 'her foolish little signature scribbled across various passages of carefully timed, edited and considered work. ${ }^{\text {, lxxix }}$ The redemptive fantasy was destroyed.

Compared with Glory! Glory! Anderson's final film, Is That All There Is? fits into the Free Cinema tradition sweetly. The titles leave no doubt about the director's intent: "Perfection is not an aim. Free Cinema Manifesto 1956." Simultaneously an onscreen television essay and a mock-documentary self-portrait, ${ }^{\operatorname{lxx}}$ it was commissioned for the BBC Scotland series 'The Director's Place' by John Archer. Anderson, like the other directors invited to depict how they lived and worked, had complete freedom within that paradigm.

He sets out as if covering a typical day in his life. Starting with his waking moments, a bath and a trip to local shops, there follow visits from friends and family and working meetings. All these scenes are full of sly humour and simmering anger at injustices in the world. Near the middle of the film (as he takes breakfast for a second time while cross-questioning his cleaner on the state of London transport) he abandons the 24-hour clock in favour of interviews. These spring traps on his guests and offer satirically oblique commentary by means of clips from TV news and other footage on the state of Britain and indeed of himself as he undergoes heart monitoring and is told that it is functioning well. This is a deeply personal film made without institutional constraint. It unflinchingly reveals British social complacency at large and also thrusts his family into the mix as his older brother Murray mouths ossified regrets over national decline. Nor does he spare himself, playing the perpetually irritating seeker after, and combatant for truth.

At Anderson's invitation Gavin Lambert wrote a personal appreciation of Is That All There Is? in February 1993. ${ }^{\text {lxxi }}$ It would eventually appear in Sight and Sound. ${ }^{\text {lxxxii }}$ While Lambert was drafting, Anderson asked his old friend whether he should have made the film nastier, but the latter thought not: 'It's more effective as more in sorrow than in anger - though with a few flashes of anger, of course.' lxxxiii Anderson accepted this but responded by reflecting on his own personality in terms which indicated that 
his attitudes had remained constant, not just since he made his decision to drop Dress Gray, but throughout most of his working life as a filmmaker.

I did think there wasn't any point in doing it unless I could make something personal. Perhaps that's always been an error of mine - to want to communicate rather than to state... You're quite right when you say that I've been reproached for not "compromising". But of course it hasn't been a decision. I just haven't been able to compromise: I don't think I'm any good at it. I suppose that's the meaning of the word "Free" in "Free Cinema". It does signify a general truth but also a particular and personal one. If I'd not felt the Liberty that comes from freedom, I just haven't been any good. Inconvenient but inescapable. ${ }^{\text {lxxiv }}$

It would be misleading to end on his note of regretful defiance for the sufficient and obvious reason that it does not encompass the range of attitudes found in the films. And indeed Is That All There Is? concludes in another register altogether, with a tenderness that finds expression, if only fleetingly, in many of his films. Anderson throws a riverboat party for old friends and colleagues to scatter in the Thames the ashes of the actors Rachel Roberts and Jill Bennett. Thus at the end, helped by Alan Price singing Peggy Lee's title song, the film switches to the opposite attitude, affectionately expressing the loyalty of friends who have gathered to mourn with dignity, tears and laughter two of the best loved actors in their circle.

Transmission was held back almost two years until the series of six personal films in 'The Director's Place' season was complete. As matters turned out, Is That All There Is? was slated for mid September 1994, but Anderson did not live to see the broadcast, dying at the end of August. Inadvertently, he had made one of the many obituaries that marked his death - and this, the release of his last Free Cinema film.

We might have included in the foregoing three other unmade films: The Private Death of Joe Stalin (a horror-comic melodrama), When The Garden Gnomes Began to Bleed (an autobiographical comedy based on David Sherwin's life as a struggling writer), and The Monster Butler (a satirical horror comedy). In fact we accepted Anderson's account of these scripts as mainly Sherwin's work. In all we have identified seventeen screen projects that followed O Lucky Man! and drew on Anderson's input as writer or director. He saw six through to completion, five of 
which (In Celebration, The Old Crowd, Britannia Hospital, The Whales of August and Is That All There Is?) adopted some or all the Free Cinema values, with Glory! Glory! the exception. Concerning the eleven projects he did not finish, we can be sure that four, Vile Bodies, If (2)...., If You Were There (Wham! in China) and The Cherry Orchard would have revealed a debt to the same legacy. The Grand Babylon Hotel was a costly period drama. We have insufficient evidence to judge Report from the Sex Factory. That leaves five, from four of which, unhappy with their scripts, Anderson withdrew (The Eyes of Laura Mars, Edward II, In a Lonely Place and Empire). As to the fifth, Dress Gray, he turned it down in favour of Britannia Hospital. To the end of his life it seems that Anderson preferred working in, or close to the Free Cinema mode.

\footnotetext{
i Lindsay Anderson, Diary, 1 January 1985 (LA/6/1/77/23-4).

ii $\quad$ Lindsay Anderson, Free Cinema 1956 - ? An essay on film (Thames
} Television, March 1986).

iii Penelope Houston, 'Parker, Anderson, Attenborough' Review of British Cinema: a Personal View, Sight \& Sound (1986) p.154 (LA/2/5/6/3/7).

iv Brian Baxter, 'The Mission Impossible,' Films and Filming (July 1986) 14-16 $(\mathrm{LA} / 2 / 3 / 6 / 5 / 1)$.

v Richard Last, 'One Man’s Cinema,' Daily Telegraph (20 March 1986) n.p. (LA/2/5/6/3/5); Walter Burns, 'Off Screen,' Time Out [March 1986] 51 (LA/2/5/6/3/23).

vi Correspondence, Anderson to Gavin Lambert, 7 July 1976 (LA/5/4/2/3).

vii Correspondence, Sidney H. Levin (Columbia Pictures) to Monty White (Anderson's Accountant), 29 April 1977 (LA/5/4/2/10).

viii Correspondence, Gavin Lambert to Anderson, 16 June 1976 (LA/5/4/2/3); Anderson to Stanley Jaffe, 14 March 1977 (LA/5/4/2/5).

ix Notes on the film by Anderson and Gavin Lambert (LA/5/4/2/2).

x Gavin Lambert, The Grand Babylon Hotel, First draft screenplay (7 March 1977) (LA/5/4/2/4).

xi Correspondence, Anderson to Gavin Lambert, 30 March 1977 (LA/5/4/2/3).

xii Correspondence, Anderson to Daniel Melnick, CEO Columbia Pictures, 24

March 1977 (LA/5/4/2/5). 
xii Correspondence, Anderson to Lambert, 30 March 1977 (LA/5/4/2/3).

xiv Correspondence, Anderson to Boaty Boatwright (Columbia British Productions Ltd.), 12 April 1977 (LA/5/4/2/5).

xv Correspondence, Anderson to Beryl Vertue (RSO Television), 12 April 1978; Anderson to Rae Knight (Robert Stigwood Organisation), 26 April 1978 (both LA/5/4/3/2); Anderson to Roy Skeggs (producer, Edward II), 12 April 1978 (LA/5/4/3/3).

xvi Correspondence, Anderson to Annabel Davis-Goff, 14 January 1976 (LA/5/4/5/1).

xvii Ibid.

xviii Correspondence, Annabel Davis-Goff to Anderson, 28 January 1976 $(\mathrm{LA} / 5 / 4 / 5 / 1)$.

xix Correspondence, Leo Greenfield (Warner Bros.) to Michael Medwin (producer), 11 February 1974 (LA/1/7/3/5/30).

xx Writer in the 1960s of films including Help!, The Knack and Tony Richardson's The Charge of the Light Brigade, and subsequent TV drama including Sharpe and Inspector Morse.

xxi Correspondence, Anderson to Charles Wood, 27 June 1980 (LA/5/4/5/4).

xxii Correspondence, Anderson to Robert Solo, 27 June 1980 (LA/5/4/5/2);

Anderson to Joanne Nici, 24 May 1983 (LA/5/4/5/1).

xxiii Note on the writing of Report from the Sex Factory, n.d. (LA/5/4/7/2).

xxiv Correspondence, Anderson to Allyn Stewart (20 Century Fox), 3 December $1979(\mathrm{LA} / 5 / 4 / 7 / 2)$.

xxv Warner Bros. inter-office correspondence from Allyn Stewart to Sandy Lieberson, 6 October 1979 (LA/5/4/7/2).

xxvi Correspondence, Tim Hampton (20 $0^{\text {th }}$ Century Fox $)$ to Anderson, 18 September $1980(\mathrm{LA} / 5 / 4 / 7 / 2)$.

xxvii Correspondence, Anderson to Gene Moskowitz, 9 June 1980 (LA/5/4/6/15).

xxviii [Ian Rakoff,] 'The Sex Factory,' annotated by Lindsay Anderson (LA/5/4/7).

xxix Correspondence, Anderson to Alan Bennett, 21 October 1977 (LA/2/3/3/1/1).

See also Alan Bennett, The Writer in Disguise (London: Faber and Faber, 1985) 12-

13. Anderson's introduction to the collaboration was reprinted as 'The Old Crowd' in 
Lindsay Anderson, Never Apologise: The Collected Writings, ed. Paul Ryan (London: Plexus, 2004), 137-47.

xxx Exceptions include Erik Hedling, Lindsay Anderson: Maverick Film-Maker (London: Cassell, 1998) 155-64; John Izod, Karl Magee, Kathryn Hannan and Isabelle Gourdin-Sangouard, Lindsay Anderson: Cinema Authorship (Manchester: Manchester University Press, 2012) Chapter 9; and Peter Hoskin, The Old Crowd, bfi Screenonline http://www.screenonline.org.uk/tv/id/860266/index.html Accessed 23 January 2014.

xxxi Hedling, Lindsay Anderson, 155.

xxxii Hoskin, The Old Crowd.

xxxii Anderson, 'Free Cinema' (1957) in Never Apologise, 75.

xxxiv Free Cinema 1, Programme, February 1956 (LA 1/2/5/4).

xxxv Anderson, Never Apologise, 147.

xxxvi Gerald Pratley, '35 days in Toronto,' Sight \& Sound, 58, 2 (Spring 1989) 94.

xxxvii Correspondence, Anderson to Mike Medavoy (Orion Pictures), 28 November $1979(\mathrm{LA} / 5 / 4 / 8 / 11)$.

xxxviii Correspondence, Anderson to Anthony Ramsay, 24 October 1980 (LA/5/4/8/19).

xxxix Tony Vidal, Orion interoffice reader's report on Empire, 9 September 1980 (LA/5/4/8/8).

xl Correspondence, Anderson to Marcia Nasatir (Producer), 24 June 1981 (LA/5/4/8/12).

xli Invoices for airfares, 16 February 1981 (LA/5/4/9/3); Notes on casting and auditions for Dress Gray (LA/5/4/9/5).

xlii See transcript of discussion between Anderson and Clive Parsons, 28 December 1980 (LA/1/9/2/2).

xliii Anderson, Diary, 30 December 1980 (LA/6/1/81) (Anderson’s ellipses).

xliv Claver Salizzato, 'Tanto libero che non si sa cosa sia,' Rinàscita, 20 January 1982 n.p. (LA/1/2/6/4/1).

xlv Anderson to Satyajit Ray, 6 January 1982 (LA/5/1/2/44/13).

xlvi Lindsay Anderson interviewed by David Robinson, 'Stripping the veils away,' The Times (21 April 1973) Review, 7 (LA/1/7/6/2/1).

xlvii Hedling, Lindsay Anderson, 185-6. 
xlviii The present authors have written at length on Anderson's authorship, see Izod et al, Lindsay Anderson: Cinema Authorship.

xlix Izod et al, Lindsay Anderson: Cinema Authorship, 216-9.

1 If (2).... (LA/5/4/10/1-16).

li Correspondence, Colin Vaines (National Film Development Fund) to Anderson, 30 June 1986 (LA/5/4/10/19).

lii For example in a letter to Gavin Lambert (23 March 1994) Anderson wrote: "I did manage to squeeze that first draft of If (2)... by collaboration with David Sherwin, and we've had it typed out and sent off to Paramount. I don't for a moment imagine they'll ever want to produce it. But at least David should be saved from imminent foreclosure which has been threatened by his bank." (LA/5/1/2/26/101).

liii See http://www.youtube.com/watch?v=GpQ9VbOjqSU accessed 28 January 2014.

liv Foreign Skies was screened at Wham!'s farewell concert, Wembley Stadium, 28 June 1986. See http://www.youtube.com/watch?v=-fDGYo0BcOI accessed 28 January 2014.

lv Lindsay Anderson, 'If You Were There formerly known as Wham! In China!' Open letter to the crew, November 1985 (LA/1/10/3/7/1).

lvi Correspondence, Anderson to Karen Cooper, Director, Film Forum New York who had asked if she could screen the film, 20 June 1985 (LA/1/10/3/2/2).

lvii If You Were There... is discussed in Izod et al., Lindsay Anderson: Cinema Authorship, 302-5.

lviii Correspondence, Mike Kaplan to Nicolas Gaster, 29 December 1986 and 7 January 1987 (LA/1/11/3/7/1-3); Nicolas Gaster to Anderson,16 January 1987 (LA/1/11/3/7/4).

lix Correspondence, Mike Kaplan to Anderson, 2 May 1986 (LA/1/11/3/1/4).

lx Louis Marcorelles, 'Anglais, encore et toujours,' Le Monde 6-7 September 1987 n.p. (LA/1/11/3/13/4).

lxi Jean-Philippe Guerand, 'Le Jeu du Solitaire,' Première May 1987 n.p. (LA/1/11/6/1).

lxii Marc Sigsworth, Verbatim transcript of discussion between Anderson and David Storey on rewriting the original script of The Whales of August for cinema (LA/1/11/1/3). 
lxiii In relation to In Celebration see Myron Galloway, 'Imparting Directives,' Montreal Gazette (no details) (LA/1/8/6/1/26).

lxiv Correspondence, Anderson to Jack Tinker (Daily Mail), 9 February 1976 (LA/5/1/1/59/24).

lxv Correspondence, Anderson to Carole Brandt, 25 June 1975 (LA/1/8/3/6/2).

lxvi Archer Winsten 'Rages and Outrages' New York Post (17 March 1975) 18 (LA/1/8/6/1/22).

lxvii Correspondence, Anderson to Paul Leaf, 27 February 1975 (LA 1/8/3/4/6).

lxviii Benedict Nightingale, Review of the film In Celebration, transcript of Critic's Forum, BBC Radio 3, Producer Philip French. Tx 12 June 1976 (LA/1/8/6/4/1). lxix Anton Chekhov, The Cherry Orchard, adapted for the screen by Lindsay Anderson and Frank Grimes. Second draft, Yaffle Films, March 1993 (LA/5/4/14/6). lxx See Kevin Thomas, 'Family Life in Maine and Sicily,' Los Angeles Times (23 October 1987) Part VI, 1, 25 (LA/1/11/6/2); Alexander Walker, 'On golden coast,' Evening Standard (26 May, 1988) 32 (LA/1/11/6/3).

lxxi Correspondence, Bonny Dore to Anderson, 4 March 1988 (LA/2/7/3/1/1); Anderson, Diary, 23 May 1988 (LA/6/1/90/20).

lxxii Anderson, Diary, 16 June 1988 (LA/2/7/2/6/10) and 2 July 1988 (LA/2/7/2/6/22-3).

lxxiii Anderson, Diary, 30 March 1988 (LA/6/1/90/13).

lxxiv $\quad$ See Izod et al., Lindsay Anderson: Cinema Authorship, 270-2, 275-7.

lxxv Anderson, Diary, 15/16 September 1988 (LA/2/7/2/6/52).

lxxvi Anderson, Diary, 14 August 1988 (LA/2/7/2/6/50).

lxxvii Anderson, Diary, 3 October 1988 (LA/2/7/2/6/61).

lxxviii Anderson, Diary, 21 September 1988 (LA/2/7/2/6/58).

lxxix Anderson, Diary, 13 November 1988 (LA/2/7/2/6/ n.p.).

Ixxx Is That All There Is? is discussed by Gavin Lambert, 'Lindsay Anderson: Unrequited Lover,' Sight and Sound 4, 10 (October 1994) 18-21; and Izod et al., Lindsay Anderson: Cinema Authorship, 280-9.

lxxi Gavin Lambert, Typescript Is That All There Is? (LA/2/9/6/3).

Ixxxii Gavin Lambert, 'Lindsay Anderson: Unrequited Lover,' Sight and Sound 4, 10 (October 1994) 18-21.

lxxxiii Correspondence, Gavin Lambert to Anderson, 8 February 1993 (LA/2/9/3/6/1). 
lxxxiv Correspondence, Anderson to Gavin Lambert, 17 February 1993 $(\mathrm{LA} / 2 / 9 / 3 / 6 / 2)$. 